\title{
DILEMA PERS BIROKRATIK DI ERA DEMOKRATISASI STUDI KASUS TABLOID KOMUNIKA KEMENTERIAN KOMUNIKASI DAN INFORMATIKA
}

\author{
Nursodik Gunarjo \\ Direktur Kemitraan Komunikasi \\ Kementerian Komunikasi dan Informatika \\ Email: gunarjo@yahoo.com \\ Y.A. Nunung Prajarto \\ Fakultas Ilmu Sosial dan Ilmu Politik Universitas Gadjah Mada \\ Ageng Setiawan Herianto \\ Fakultas Pertanian, Universitas Gadjah Mada
}

\begin{abstract}
This study aims to analyze the dilemma in the bureaucratic press Tabloid Komunika (TK) of the Ministry of Communication and Information Technology of the Republic of Indonesia. TK chosen as the study site because it was published by government institution formerly known as Ministry of Information, which very repressive to the press in New Order era. The study uses case study approach reinforced by survey and content analysis methods. From the results of the study found, most graphic indicator of the freedom of journalists, public sphere openess, and the determination of the content, showed a random trend, while the freedom of access and opportunity of expression showed a rising trend. Inconsistencies in the implementation of elements of press democracy showed the dilemma in TK. Factors causing a dilemma in TK are: inconsistent leadership, unclear structure and functions of TK's organization, and uncertainty management attitude. Bureaucratic power pressure lead TK's organizers confused to divide partisanship to the community or the government. Dilemma in TK causes ambiguous contents, more actualized public opinion but the tone of articles are neutral toward the government.
\end{abstract}

Keywords: Ambiguity, press democracy, dilemma, bureaucratic press.

\section{ABSTRAK}

Tulisan ini bertujuan menganalisis dilema di dalam pers birokratik Tabloid Komunika (TK) Kementerian Komunikasi dan Informatika Republik Indonesia. TK dipilih sebagai lokasi penelitian karena diterbitkan oleh lembaga yang cikal-bakalnya adalah Departemen Penerangan, yang pada masa Orde Baru sangat represif terhadap pers. Penelitian menggunakan pendekatan studi kasus yang diperkuat dengan metode survei dan analisis isi. Dari hasil penelitian ditemukan, sebagian besar grafik indikator dari kebebasan wartawan, keterbukaan ruang publik, dan penentuan isi, menunjukkan tren acak, sedangkan keleluasaan akses dan kesempatan ekspresi menunjukkan tren meningkat. Inkonsistensi dalam implementasi elemen demokrasi pers menunjukkan adanya dilema di TK. Faktor menyebabkan dilema di TK adalah: inkonsistensi pimpinan, struktur dan fungsi organisasi yang tidakjelas, dan ketidakpastian 
sikap pengelola. Tekanan kekuasaan birokrasi menyebabkan pengelola TK bingung membagi keberpihakan kepada masyarakat atau pemerintah. Dilema menyebabkan isi TK ambigu, lebih banyak mengaktualisasikan pendapat masyarakat umum, akan tetapi mayoritas nada artikelnya netral terhadap pemerintah.

\section{Kata kunci: Ambigu, demokrasi pers, dilema, pers} birokratik.

\section{PENGANTAR}

Dilema adalah situasi yang membingungkan karena mengharuskan orang melakukan pilihan antara dua kemungkinan yang keduanya tidak menyenangkan. Sedangkan demokratisasi pers birokratik adalah upaya mengubah peran dan fungsi pers birokratik yang semula semata-mata berpihak kepada pemerintah, menjadi berpihak kepada masyarakat. Pemilihan fokus kajian didasari fakta, pers birokratik diterbitkan dengan dana masyarakat akan tetapi kebanyakan isinya tidak berpihak kepada masyarakat (Gunarjo, 2006:12).

Tabloid Komunika (TK) yang diterbitkan oleh Kementerian Komunikasi dan Informatika (Kemkominfo) Republik Indonesia. Pemilihan TK sebagai objek analisis didasarkan pada tiga alasan. Pertama, TK dikelola oleh satu-satunya kementerian yang tugas pokok dan fungsinya di bidang komunikasi dan informatika. Kedua, Kemkominfo adalah lembaga yang secara resmi menjalankan fungsi kehumasan pemerintah atau government public relation/ GPR, dengan demikian TK adalah media resmi humas pemerintah. Ketiga, keberadaan TK unik karena dikelola oleh lembaga yang cikal-bakalnya adalah Departemen Penerangan (Deppen), lembaga yang pada zaman Orde Baru dikenal represif terhadap pers. Keunikan TK ini memenuhi syarat sebagai objek studi kasus (Yin, 2008:48).

Analisis dilakukan untuk menjawab tiga pertanyaan sebagai berikut: (1) Bagaimana dilema di Tabloid Komunika; (2) Mengapa terjadi dilema di Tabloid Komunika? (3) Bagaimana akibat dilema terhadap isi Tabloid Komunika? Adapun tujuannya untuk mendeskripsikan secara lengkap dan mendalam dilema yang terjadi dalam seluruh aktivitas jurnalistik di TK, menemukan dan menjelaskan faktor-faktor yang menyebabkan terjadinya dilema di TK, serta menguraikan akibat dilema terhadap isi TK.

Pers birokratik masih menunjukkan kecenderungan keberpihakan sematamata kepada pemerintah. Sebagian besar isi Buletin Siaran Umum terbitan Deppen berpihak kepada kepentingan pemerintah (Suroto, dkk:1992). Swardhana (2000) juga menemukan bukti teras berita yang dimuat di dalam Buletin Jatim Newsroom milik Dinas Informasi dan Komunikasi Provinsi Jawa Timur didominasi oleh pejabat pemerintah. Gunarjo (2006) menemukan bukti bahwa frekuensi subjektivitas isi Buletin Berita Infokom Jatim sangat tinggi karena di antaranya terlalu banyak isi yang memihak kepada pemerintah. Direktorat Publikasi Departemen Penerangan (1983; 1988; 1993; 1998) menemukan bahwa berbagai jenis media massa yang dipergunakan Deppen belum mampu mendorong terjadinya komunikasi timbal-balik secara efektif antara pemerintah dan masyarakat. Departemen Penerangan (1998) menunjukkan bahwa pesan-pesan yang disampaikan Deppen belum memenuhi kebutuhan masyarakat. Hasil penelitian Pusat Penelitian Sumber Daya Manusia dan Lingkungan Universitas Padjadjaran Bandung (2000) menemukan bukti bahwa aktivitas penerangan Deppen tidak mendapatkan perhatian memadai dari masyarakat sehingga perlu pendekatan penerangan yang lebih demokratis, bottomup, dan berpusat pada masyarakat. Sementara penelitian Departemen Penerangan dan Pusat Penelitian dan Pengembangan Pers dan Pendapat Umum (1980) menemukan bukti bahwa penerbitan khusus Deppen dinilai terlalu banyak menyediakan ruang bagi pemerintah dan sebaliknya tidak menyediakan ruang memadai bagi ekspresi masyarakat.

Fortner (1993:221), sistem pers tidak dapat dipisahkan dari pengaruh internal 
maupun eksternalnya. Komponen yang berpengaruh terhadap sistem pers di antaranya komponen teknis, ekonomi, politik, sosial, dan budaya. Pengaruh tersebut menyebabkan sistem pers terus bertransformasi. Dalam proses transformasi, semua sistem melakukan diferensiasi. Ada tiga kemungkinan akibat diferensiasi, sistem tidak terpengaruh, sangat terpengaruh, atau berada pada perebutan pengaruh sistem lain yang ada di lingkungannya (Maturana, 1981:89). Akibat diferensiasi yang terakhir, sistem dapat mengalami situasi dan kondisi dilematis. Dilema adalah "situasi yang mengharuskan orang melakukan pilihan antara dua kemungkinan yang kedua-duanya tidak menyenangkan; situasi yang sulit dan membingungkan" (http://bahasa.kemdiknas. go.id/kbbi/index.php). Salah satu jenis dilema adalah double bind, yaitu dilema yang terjadi saat individu atau kelompok menerima dua atau lebih pesan yang saling menegasikan sehingga keberhasilan merespon satu pesan akan menghasilkan kegagalan merespon pesan lainnya (Bateson dkk, 1956:250). Sementara di dalam lingkup jurnalistik dikenal istilah dilema media massa, yaitu kebimbangan pekerja media massa karena di satu sisi ingin mendahulukan kebebasan yang mereka miliki, di sisi lain harus melaksanakan keberpihakan sebagaimana diarahkan oleh organisasi atau pimpinan pers (McQuail, 1987:181).

Pers birokratik atau sering disebut dengan istilah pers pemerintah adalah pers yang diterbitkan oleh lembaga pemerintah (Arifin, 2000:8). Istilah lain yang digunakan untuk menyebut pers birokratik adalah state press atau state-owned press (Webster, 1992:17). Asumsi selama ini, pers birokratik selalu tunduk kepada birokrasi pemiliknya. Namun di negara liberal dan negara demokrasi, pers birokratik dapat meneguhkan posisinya untuk berseberangan dengan pemerintah (Hallin dan Mancini, 2004:67). Di banyak negara maju yang demokratis, pers birokratik dapat melakukan peliputan sebagaimana pers swasta independen yang bebas dari kontrol negara (McQuail, 1987:237). Akan tetapi, di negara berkembang, pers birokratik pada umumnya berada di bawah kendali pemerintah karena biasanya digunakan untuk tujuan propaganda dan penyambung lidah untuk mendukung ideologi rezim berkuasa (Karatnycky dkk, 2002: 99). Pers birokratik biasanya melegitimasikan posisi tersebut dengan alasan untuk menjaga persatuan dan kesatuan bangsa (Hoffmann-Riem, 1996: 259). Perbedaan karakteristik pers birokratik tersebut juga dapat menimbulkan dilema.

Berdasarkan public choice theory, kepemilikanpersolehnegaratidakdiperlukan karena berpotensi menimbulkan manipulasi dan distorsi informasi oleh kekuatan politik dan para pemegang kekuasaan (Djankov dkk, 2003:341). Sedangkan public interest theory yang mengacu pada teori Pigouvian (Coase, 1950) menyebutkan, kepemilikan pers oleh negara diperlukan atau bahkan diinginkan karena informasi merupakan hak warganegara yang wajib disediakan pemerintah secara cuma-cuma. Demokratisasi pers birokratik berangkat dari asumsi dasar bahwa informasi, budaya, dan ide merupakan public goods yang menjadi properti kolektif milik bersama. Sebagaimana public goods lainnya seperti air dan udara, ketersediaannya bagi masyarakat tidak perlu dibatasi (McQuail, 2000). Oleh karena itu, pers termasuk pers birokratik, seharusnya menyediakan informasi bagi semua orang tanpa pembatasan-pembatasan.

Sistem pers demokratis memiliki tiga karakteristik. Pertama, terdapat independensi pers dari campurtangan pemerintah, profesional, maupun pasar; Kedua, adanya akuntabilitas pers baik kepada masyarakat umum maupun kepada khalayaknya; Ketiga, adanya jaminan keberagaman (Cuilenberg dan McQuail, 1998:67). Adapun prinsipprinsip demokrasi pers sebagai berikut:

Pertama adalah Kebebasan wartawan. Asumsi dasarnya, kebebasan pers harus diarahkan agar memberikan manfaat nyata bagi masyarakat, bukan sekadar membebaskan dari kekuatan eksternal (McQuail, 2002:208). Kebebasan pers dapat 
menjadi sarana public empowerment karena menghendaki peran serta masyarakat sebagai kekuatan sosial, serta negara dan aparaturnya sebagai kekuatan politik untuk turut membangun dan mendorong demokratisasi pers. (Severin \& Tankard, 2005:373).

Kedua adalah Keleluasaan akses. Akses terhadap pers dalam masyarakat modern telah menjadi sebuah keharusan untuk mewujudkan kewarganegaraan (Wasburn, 1995:69). Keleluasaan akses ditujukan untuk menjamin ketersediaan informasi di tengah masyarakat secara beragam, sehingga masyarakat dapat memilih informasi sesuai kebutuhannya (Subiakto, 2001:61-80). Keleluasaan akses tergantung pada jumlah dan jenis media, kemampuan menjangkau dan dijangkau khalayak, dan keragaman isi yang disampaikan (McQuail, 2000:241).

Ketiga adalah Keterbukaan ruang publik. Ruang publik publisitas hendaknya dapat digunakan masyarakat untuk berdiskusi, menyampaikan opini, mengartikulasikan kepentingan dan kebutuhan, serta menyatakan sikap dan argumen terhadap negara dan pemerintah secara bebas dan terbuka (Habermas, 1989:328).

Keterbukaan ruang publik publisitas dapat dilihat dari kemampuan pers menyajikan pendapat berbeda dari masyarakat atas isu-isu aktual yang sedang berkembang (McNair, 1999:21-22). Pertama, Tidak adanya dominasi dalam penetapan isi. Meskipun tidak mungkin mewujudkan pers bebas yang tanpa tekanan eksternal, namun pers seyogyanya mampu menciptakan dan memelihara independensinya, serta menolak kontrol eksternal yang dipaksakan atau kompromi dengan kelompok tertentu (McQuail, 2000:172). Kedua, Kesempatan ekspresi adalah peluang bagi seluruh anggota masyarakat untuk dapat menyampaikan opini yang beragam melalui pers. Oleh karena itu, narasumber pers seharusnya tidak didominasi oleh orang-orang dari kalangan mayoritas, namun juga membuka peluang bagi kelompok minoritas untuk bersuara (Subiakto, 2000:61-80).
Kendala demokratisasi di pers birokratik pada umumnya terjadi karena pers birokratik difungsikan sebagai media humas pemerintah. Padahal di negara berkembang, humas pemerintah biasanya direkayasa secara politis untuk pencitraan lembaga atau pejabat pemerintah (Kusumastuti, 2002:59). Hegemoni kekuasaan politik sering membuat humas pemerintah sengaja melakukan kebohongan, penipuan, pengingkaran, dan rekayasa informasi demi kebutuhan rezim (Olusegun, 2006:77). Jika dua fungsi tersebut secara simultan harus dilaksanakan oleh pers birokratik, maka munculnya dilema menjadi hal yang sulit untuk dihindari.

Pendekatan penelitian menggunakan studi kasus (case study), yaitu strategi analisis di mana di dalamnya peneliti menyelidiki secara cermat suatu program, peristiwa, aktivitas, proses, atau sekelompok individu (Creswell, 2010:241). Jenis studi kasus yang dipilih adalah studi kasus tunggal holistik, yang menyelidiki satu kasus pada satu tempat secara menyeluruh dan mendalam (Yin, 2008:47). Data dalam penelitian studi kasus dikumpulkan melalui enam sumber bukti, yaitu dokumen tercetak (diperkuat dengan hasil analisis isi), rekaman arsip, transkrip wawancara (diperkuat dengan hasil survei), hasil pengamatan langsung, hasil pengamatan berperanserta, dan perangkat fisik (Yin, 2008:103-118). Pada analisis data dilakukan dengan teknik analisis data kualitatif sesuai protokol studi kasus.

\section{PEMBAHASAN Keadaan Umum Demokratisasi Pers di TK}

Demokratisasi di TK mulai diterapkan pada tahun 2005, diawali dengan mengadopsi dan menerapkan sistem keredaksian yang biasa dipakai dalam organisasi pers profesional serta membentuk newsroom baru yang lebih representatif untuk tugas-tugas jurnalistik. Jika pada zaman Deppen newsroom lebih berfungsi sebagai ruang kontestasi pejabat pemerintah, maka newsroom yang baru dibentuk diupayakan dapat berfungsi sebagaimana newsroom pers profesional yaitu 
murni sebagai tempat untuk mengumpulkan, mengolah, dan menyebarluaskan informasi.

Berbagai bentuk demokratisasi yang telah dilaksanakan di TK di antaranya: (1) Redaktur dan reporter diberi kebebasan untuk melaporkan dan mengomentari isu-isu yang sedang menjadi perhatian masyarakat; (2) Perencanaan isi yang semula bersifat top down secara bertahap diubah menjadi perencanaan dari bawah; (3) Sensor isi oleh pejabat struktural nonredaksi dikurangi dan dalam jangka panjang akan dihapuskan; (4) Terus melakukan upaya agar di masa datang isi dapat mewakili aspirasi masyarakat (Badan Informasi Publik, 2008:8).

Akan tetapi, demokratisasi pers belum dapat terlaksana dengan baik di TK hingga tahun 2010 karena adanya fenomena dan hal ini disebut sebagai "ambiguitas" (McQuail, 1987:277). Ambiguitas terjadi karena di satu sisi Kemkominfo menghendaki agar TK bisa berfungsi sebagai wahana demokratisasi, tetapi di sisi lain juga menekankan agar TK mampu menjadi government public relation atau humas pemerintah yang baik (Biro Umum dan Humas, 2007:10). Praktik di TK, fungsi humas pemerintah diterjemahkan sebagai keharusan memuat keberhasilan pemerintah, bahkan lebih jauh lagi, melakukan pencitraan bahwa apa yang dilakukan pemerintah sudah baik dan benar. Fungsi tersebut tidak dapat disatukan dengan fungsi pers sebagai wahana demokratisasi karena secara teoritis keduanya saling bertolak-belakang. "In a democracy, press and government cannot be partners. They are natural adversaries with different functions" (Sullivan, 2009:8). Situasi yang konfliktual semacam itu membuat pers birokratik berada dalam situasi dilematis. Dilema paling mendasar dialami oleh para redaktur, wartawan, reporter, dan koresponden yang sehari-hari melaksanakan pekerjaan inti pers. Dilema terjadi karena adanya kebebasan versus pembatasan atau kendala dalam institusi pers. Para pekerja pers tersebut menilai tinggi orisinalitas dan kebebasan, tetapi latar belakang organisasinya menuntut adanya kontrol dan pembatasan yang ketat (McQuail, 1987:149).

\section{Dilema di TK}

Temuan terkait dilema di TK dianalisis melalui implementasi empat elemen demokrasi pers, yaitu Pertama adalah dilema terkait Kebebasan Wartawan bahwa dilema terkait kebebasan wartawan ditinjau melalui empat indikator meliputi: (1) Kebebasan mengajukan inisiatif liputan; (2) Kebebasan menentukan target liputan; (3) Kebebasan dari sensor; dan (4) kebebasan wartawan dari sanksi terkait kegiatan jurnalistik. Hasil analisis tentang dilema terkait kebebasan wartawan di TK dapat dilihat pada tabel berikut:

Tabel 1. Dilema terkait kebebasan wartawan Tabloid Komunika

\begin{tabular}{|c|c|c|}
\hline \multicolumn{3}{|c|}{ Keberpihakan kepada } \\
\hline Pemerintah & & Masyarakat \\
\hline $\begin{array}{l}\text { - Pasif mengajukan inisiatif liputan } \\
\text { - Menerima instruksi liputan dari pejabat } \\
\text { - Menerima sensor dlm pemuatan hasil liputan } \\
\text { - Menerima sanksi terhadap wartawan }\end{array}$ & $\begin{array}{l}\mathrm{V} \\
\mathrm{S}\end{array}$ & $\begin{array}{l}\text { - Aktif mengajukan inisiatif liputan } \\
\text { - Menolak instruksi liputan dari pejabat } \\
\text { - Menolak sensor dlm pemuatan hasil liputan } \\
\text { - Menolak sanksi terhadap wartawan }\end{array}$ \\
\hline
\end{tabular}

Dilema terkait kebebasan wartawan terjadi karena tidak adanya kejelasan kebebasan yang ada akan digunakan secara kompromistis atau kritis (McQuail, 2000). Di TK, kebebasan tampaknya sengaja dibiarkan berada dalam situasi chaostic, kadang sangat bebas, kadang sangat tidak bebas. Dampaknya, pengelola TK mengalami kebimbangan harus mengarahkan kebebasan itu kepada pemerintah atau masyarakat. Pada saat kebimbangan terjadi, situasi yang ada dengan mudah dapat dihegemoni oleh 
pejabat untuk menekan kebebasan wartawan untuk berpihak kepada pemerintah. Hal itu menunjukkan bukti bahwa TK adalah pers dominatif yang dikuasai oleh segelintir orang kuat (McQuail, 1987:63). Adanya aktor dominan menyebabkan informasi dapat dikuasai secara sepihak oleh perorangan (Fortner, 1993), tidak mentoleransi kebebasan pers mutlak yang dapat menyebabkan pemerintah kebanjiran kritik (Pool, 1973:47).
Kedua adalah dilema terkait Keleluasaan Akses bahwa dilema terkait keleluasaan akses ditinjau dari indikator: jumlah tiras, jumlah pembaca tertarget, jumlah pembaca tertarget yang tidak terlayani, jumlah media lain untuk menyebarkan isi, dan jumlah hit pengunjung TK online. Ikhtisar dilema terkait keleluasaan akses dapat dilihat pada tabel berikut:

Tabel 2. Dilema terkait keleluasaan akses di Tabloid Komunika

\begin{tabular}{|c|c|c|}
\hline \multicolumn{3}{|c|}{ Keberpihakan kepada } \\
\hline Pemerintah & & Masyarakat \\
\hline - Tidak menambah jumlah tiras & & - Menambah jumlah tiras \\
\hline - Tidak menambah jml pembaca tertarget & & - Menambah jumlah pembaca tertarget \\
\hline $\begin{array}{l}\text { - Tidak mengurangi jumlah pembaca tertarget } \\
\text { yang tidak terlayani }\end{array}$ & s & $\begin{array}{l}\text { - Mengurangi julah pembaca tertarget yang } \\
\text { tidak dilayani }\end{array}$ \\
\hline $\begin{array}{l}\text { - Tidak menambah media lain untuk } \\
\text { menyebarkan isi TK }\end{array}$ & & $\begin{array}{l}\text { - Menambah media lain untuk menyebarkan } \\
\text { isi TK }\end{array}$ \\
\hline - Tdk menambah hit pengunjung TK online & & - Menambah hit pengunjung TK online \\
\hline
\end{tabular}

Dilema terkait keleluasaan akses terjadi karena pengelola ingin meningkatkan extensive reach atau kemampuan menjangkau dan dijangkau khalayak. Akan tetapi, keinginan itu terkendala dana yang hanya dapat dipergunakan untuk menerbitkan TK 15.000 eksemplar. Jumlah tersebut terlalu kecil jika dibandingkan dengan wilayah yang harus disasar. Kendati sejak diterbitkan jumlah tiras terus bertambah, tetapi persebarannya juga tidak merata hingga ke daerah perdesaan terpencil, daerah perbatasan dan pulau-pulau terluar. Masih adanya wilayah blank spot, membuat sebagian warganegara tertutup dari informasi yang bermakna bagi mereka (Subiakto, 2001:6180). Sedikitnya jumlah tiras menyebabkan keinginan meningkatkan jumlah pembaca tertarget tidak terwujud. Banyaknya pembaca tertarget yang tidak menerima TK semakin mempersempit keleluasaan akses terhadap TK. Sementara jumlah media lain untuk menyebarkan isi TK kendati mengalami peningkatan, yaitu melalui internet, hit pengunjung TK online belum optimal. Padahal seiring makin memudarnya pamor media tercetak (Steemers, 2000:228), TK seharusnya secara dini menggandeng media massa noncetak termasuk media baru. Penggunaan berbagai jenis media secara terintegrasi diharapkan dapat memperbesar aksesibilitas masyarakat (Dhakidae, 2007).

Ketiga adalah dilema terkait Keterbukaan Ruang Publik bahwa dilema terkait keterbukaan ruang publik ditinjau dari indikator-indikator: jumlah rubrik opini, luas rubrik opini, jumlah naskah opini yang masuk ke redaksi, jumlah naskah opini yang dimuat, dan jumlah naskah opini yang tidak dimuat. Hasil penelitian tentang dilema terkait keterbukaan ruang publik dapat dilihat pada tabel berikut: 
Tabel 3. Dilema terkait keterbukaan ruang publik di Tabloid Komunika

\begin{tabular}{|c|c|c|}
\hline \multicolumn{3}{|c|}{ Keberpihakan kepada } \\
\hline Pemerintah & & Masyarakat \\
\hline $\begin{array}{l}\text { - Tidak menambah jumlah rubrik opini } \\
\text { - Tidak menambah luas rubrik opini } \\
\text { - Tdak meningkatkan jumlah naskah opini } \\
\text { yang dikirimkan masyarakat } \\
\text { - Tidak memperbesar kemampuan memuat } \\
\text { naskah opini masyarakat }\end{array}$ & $\begin{array}{l}\mathrm{V} \\
\mathrm{S}\end{array}$ & $\begin{array}{l}\text { - Menambah jumlah rubrik opini } \\
\text { - Menambah luas rubrik opini } \\
\text { - Meningkatkan jumlah naskah opini yang } \\
\text { dikirimkan masyarakat } \\
\text { - Memperbesar kemampuan memuat naskah } \\
\text { opini masyarakat }\end{array}$ \\
\hline
\end{tabular}

Dilema terkait keterbukaan ruang publik terjadi karena keinginan pengelola TK untuk menambah jumlah dan luas ruang publik di TK serta meningkatkan kemampuan TK memuat naskah opini dari masyarakat tidak mendapatkan sambutan dari pimpinan TK. Para pimpinan menganggap telah menyediakan ruang publik dalam jumlah yang cukup bagi masyarakat untuk menyampaikan aspirasi, tetapi pengeloloa beranggapan sebaliknya bahwa jumlah dan luas ruang publik yang ada di TK masih kurang. Penolakan para pimpinan untuk menambah jumlah dan luas rubrik opini menunjukkan secara tidak langsung mereka menghendaki keberadaan ruang publik di dalam TK dibatasi. Secara teoritis, semua pers menyatakan akan melayani kebutuhan dan kepentingan masyarakat serta menyebutkan keinginan untuk memberikan kesempatan kepada masyarakat, tetapi kenyataannya tidak menyediakan ruang yang cukup terbuka bagi anggota masyarakat untuk menyampaikan aspirasi (McQuail, 1987:40). Analisis ini juga menemukan, ruang publik di TK belum dapat berfungsi sebagai ruang publik dalam arti sesungguhnya. Pendapat publik yang dimasukkan ke TK sebelumnya telah dipilih dan ditapis terlebih dahulu oleh para pimpinan TK secara ketat. Oleh karena itu, ruang publik yang ada di TK lebih layak disebut sebagai ruang publik semu, karena hanya memuat pendapat yang sudah difilter, direkonstruksi, dan digunakan untuk kepentingan penguasa. Idealnya, ruang publik publisitas di dalam pers mampu menjadi ruang demokratis dan wahana diskursus masyarakat. Melalui ruang tersebut, warganegara dapat menyatakan opini, kepentingan, dan kebutuhan mereka secara diskursif. Selain itu bersifat bebas, terbuka, transparan, dan tidak ada intervensi pemerintah atau otonom di dalamnya serta mudah diakses semua orang (Habermas, 1989:328). Keempat adalah dilema terkait Penentuan Isi bahwa dilema terkait penentuan isi ditinjau melalui indikator: jumlah naskah yang dimuat atas keputusan sidang redaksi, jumlah naskah yang tidak dimuat atas keputusan sidang redaksi, jumlah naskah yang dimuat atas keputusan pejabat struktural, dan jumlah naskah yang tidak dimuat atas keputusan pejabat struktural. Hasil penelitian tentang dilema terkait penentuan isi tergambar dalam tabel 4 berikut:

Tabel 4. Dilema terkait penentuan isi Tabloid Komunika

\begin{tabular}{|c|c|c|}
\hline \multicolumn{3}{|c|}{ Keberpihakan kepada } \\
\hline Pemerintah & & Masyarakat \\
\hline $\begin{array}{l}\text { - Meningkatkan jml naskah dimuat atas } \\
\text { keputusan pejabat struktural } \\
\text { - Meningkatkan jml naskah tdk dimuat atas } \\
\text { keputusan pejabat struktural }\end{array}$ & $\begin{array}{l}\text { V } \\
S\end{array}$ & $\begin{array}{l}\text { - Meningkatkan jml naskah dimuat atas } \\
\text { keputusan sidang redaksi } \\
\text { - Meningkatkan jml naskah tidak dimuat atas } \\
\text { keputusan sidang redaksi }\end{array}$ \\
\hline
\end{tabular}


Dilema muncul karena penentuan isi TK kadang didominasi dan kadang tidak didominasi. Situasi tersebut menyebabkan kebimbangan sikap pengelola dalam proses seleksi isi TK, yaitu antara menegakkan independensi sebagaimana diinginkan pengelola atau mengakomodasi hegemoni para pejabat birokrasi. Pengelola mengalami kesulitan antara menegakkan objektivitas sebagai komunikator massa dan menjalankan peran sebagaimana dituntut oleh organisasi pers karena arah kebijakan redaksional dan implementasinya tidak konsisten (McQuail, 2000). Situasi dilematis tersebut sepertinya sengaja dipertahankan para pimpinan agar tetap ada dan digunakan sebagai alat kontrol tanpa bentuk pemaksaan terbuka karena dalam kondisi bingung atau bimbang seseorang akan mengalami kesulitan untuk menolak perintah (Bateson, 1956: 251-254).

Akan tetapi, situasi dilematis di TK tidak sepenuhnya mampu mengarahkan keberpihakan TK ke domain pemerintah. Kendati beberapa elemen demokrasi pers implementasinya secara hegemonik dapat dibelokkan agar berpihak kepada pemerintah, tetapi beberapa elemen yang lain justru menunjukkan keberpihakan kepada masyarakat. Secara keseluruhan, implementasi demokrasi pers di TK dapat disajikan dalam model eksisting dilema pada gambar 1 .

Dilema yang terjadi di TK telah mengarahkan pengelola TK untuk membagi keberpihakan, sebagiankepada pemerintahdan sebagian kepada masyarakat. Kecenderungan keberpihakan kepada pemerintah terjadi dalam implementasi elemen demokrasi pers kebebasan wartawan, keterbukaan ruang publik dan penentuan isi. Tiga elemen tersebut adalah elemen demokrasi pers yang secara teoritis paling mudah dihege-moni oleh pemegang kekuasaan, karena terkait langsung dengan keterlibatan para pimpinan dalam menentukan isi TK. Sementara keberpihakan kepada masyarakat terjadi pada implementasi elemen demokrasi pers keleluasaan akses dan kesempatan ekpresi.

Dari gambar 1 diketahui, dilema di TK pada akhirnya cenderung mengarahkan
keberpihakankepadapemerintah.Dengankata lain, pers birokratik TK di era demokratisasi ini masih tetap mempertahankan ciri-ciri pers birokratik orde baru yang kental dengan "warna" pemerintah. Kendati beberapa elemen demokrasi pers telah dilaksanakan, tetapi hegemoni aparat birokrasi pemerintah tetap terjadi.

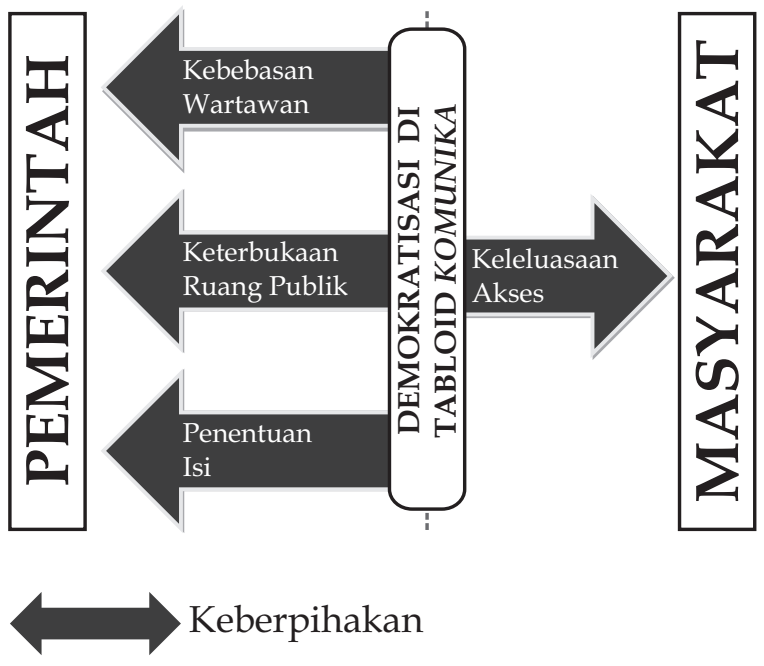

Gambar 1. Model Eksisting dilemma di Tabloid Komunika

\section{Faktor Penyebab Dilema}

Faktor utama penyebab dilema di TK adalah karena rendahnya komitmen pimpinan untuk menerapkan demokrasi pers secara utuh. Bagaimanapun organisasi pers birokratik tidak dapat lepas dari peranan, kegiatan, dan keterampilan pimpinan organisasi. Pemimpin organisasi pada umumnya dipandang sebagai orang yang memiliki kemampuan untuk dapat mempengaruhi dan menyetir orang lain agar berpikir dan bertindak sesuai dengan yang diinginkannya (Robbins, 2007:518). Rendahnya komitmen pimpinan karena tidak ada sanksi apapun jika tidak melaksanakan demokrasi pers di TK karena keberhasilan kinerja hanya diukur dari kemampuan memenuhi jumlah edisi dan kemampuan menyerap anggaran. Tidak adanya target yang ditetapkan pimpinan menyebabkan implementasi demokrasi pers berjalan lambat. Selain itu, implementasinya juga tidak dilakukan secara terpola dan terarah sehingga mudah dibelokkan. Tanpa 
penyiapan prakondisi yang baik, demokrasi yang diterapkan pada akhirnya tidak mendapatkan legitimasi baik dari dalam maupun luar organisasi (Dahl, 1999:54).

Faktor lain yang menyebabkan dilema adalah tidak adanya aturan main yang jelas tentang pola kerja pengelola TK. Kejelasan aturan main diperlukan agar pola kerja di TK dapatdiarahkansesuaikaidahdemokrasipers. Secara lebih luas, media memerlukan aturan yang menjamin independensi kebijakan dan profesionalitas awak media (McQuail, 1987:280). Tanpa aturan main yang jelas, pengelola akan diliputi kebingungan saat melaksanakan demokratisasi. Tidak jelasnya struktur organisasi TK juga turut menjadi faktor penyebab dilema. Sebagaimana diketahui, demokratisasi pers memerlukan dukungan kelembagaan yang kuat dan independen. Kuat di sini berarti organisasi pers yang ada memiliki kemampuan untuk beraktivitas secara mandiri tanpa tergantung pihak lain. Sedangkan independen artinya aktivitas organisasi pers terbebas dari campurtangan pihak-pihak di luar organisasi pers. Independensi organisasi pers sangat penting, karena dalam kenyataannya pers selalu menghadapi tekanan di antaranya dari penguasa dan institusi (Gerbner, 1969). Akan tetapi, analisis ini menemukan bukti bahwa struktur organisasi TK sengaja dibiarkan berada di antara unit kerja struktural dan nonstruktural, sehingga independensi TK tidak dapat lepas dari pengaruh birokrasi. Pada struktur organisasi pers yang setengah bebas dan setengah terikat, TK pada akhirnya berada di antara kecenderungan pers sentrifugal dan sentripetal. Kadang TK cenderung sentrifugal yang mengunggulkan gagasan perubahan, kebebasan, keanekaragaman, dan fragmentasi. Kadang juga cenderung sentripetal yang mengunggulkan ketenangan, kontrol, persatuan, dan keterpaduan (McQuail, 1987:59). Kendati secara teoritis pers cenderung menerapkan keduanya secara simultan, tetapi mencampuradukkan dua kecenderungan dalam waktu yang bersamaan akan menimbulkan kebingungan (McCormack, 1961:89).
Faktor lain yang menyebabkan dilema di dalam TK adalah adanya ambiguitas fungsi TK sebagai wahana demokrasi di satu sisi dan humas pemerintah di sisi lain. Ambiguitas fungsi tersebut turut memperbesar kebingungan pengelola dalam melakukan keberpihakan. Pada akhirnya, pengelola TK mengalami kesulitan untuk menentukan sikap yang jelas antara berpihak kepada masyarakat atau kepada pemerintah. Demokrasi pers dan pemerintah pada dasarnya tidak bisa bekerjasama karena memiliki fungsi yang berbeda. Oleh karena itu, jika keduanya dipaksakan berada dalam satu domain, akan menyebabkan fungsi pers tidak bisa berjalan maksimal (Sullivan, 2009:8).

Sementara ketidakjelasan sikap pengelola, ada yang terang-terangan mendukung, diam-diam mendukung, abstain, terang-terangan anti dan diamdiam anti demokratisasi, juga menjadi penyebab munculnya dilema di TK. Ketidakmanunggalan sikap pengelola sejatinya merupakan problema bawaan dari demokrasi yang mengizinkan perbedaan pendapat, sehingga pengelola tidak dapat diarahkan agar memiliki sikap sama terhadap demokratisasi. Akan tetapi, justru dari perbedaan pendapat itulah dilema muncul.

\section{Akibat Dilema terhadap Isi TK}

Dilema yang terjadi di dalam organisasi pers TK berpengaruh terhadap produk jurnalistik yang dihasilkan. Hal tersebut didasarkan pada teori bahwa produk akhir jurnalistik sangat ditentukan oleh aktivitas yang terjadi pada saat proses gatekeeping di ruang berita. Studi yang dilakukan White (1950); Gieber (1956); McQuail (1977) hingga Fishman (1982), semua menunjukkan hasil yang sama bahwa apa yang terjadi di ruang berita berdampak signifikan terhadap isi media yang ditampilkan kepada khalayak. Jika proses gatekeeping di ruang berita dilakukan secara demokratis, maka produk jurnalistik yang dihasilkan juga akan menggambarkan sisi demokratis tersebut. 
Demikan pula jika proses gatekeeping dilakukan dalam situasi dan kondisi yang dilematis, produk jurnalistik yang dihasilkan juga dapat diduga akan menggambarkan proses dilema yang terjadi. Dengan melihat produk jurnalistik yang dihasilkan, akan tampak bagaimana proses produk tersebut diciptakan.

Analisis isi menunjukkan bahwa mayoritas isi TK terdiri dari artikel berjenis laporan mendalam (indepth report/feature), diikuti berita langsung (spot news), opini dan lainnya. Ditinjau dari sisi peluang ketermuatan pendapat di TK, komposisi tersebut sudah ideal karena kebanyakan pendapat akan termuat di dalam artikel opini, laporan mendalam dan berita langsung. TK lebih banyak memuat pendapat masyarakat umum daripada pendapat pejabat. Kendati prosentase perbedaannya tidak terlalu mencolok karena terjadi di dalam pers birokratik, hal tersebut dapat dikatakan luar biasa. Sebagaimana diketahui, panduan keredaksian TK cenderung mengarahkan wartawan untuk memilih narasumber tokoh, yang logikanya kebanyakan terdiri dari para pejabat pemerintah. Selain itu, unsur kebernilaian berita (news value) salah satunya didasarkan pada ketokohan narasumber (Sullivan, 2009:17). Akan tetapi, bukti menunjukkan bahwa separuh lebih kutipan pendapat yang dimuat di TK adalah pendapat masyarakat umum dan sisanya merupakan kutipan pendapat pejabat.

Kendati demikian, analisis ini juga menemukan buktibahwa mayoritas pendapat yang dimuat di dalam artikel TK bukan pendapat langsung, melainkan pendapat tidak langsung. Hal itu menunjukkan bahwa TK lebih mengutamakan pendapat yang telah direkonstruksi ulang oleh wartawan. Rekonstruksi berarti melaporkan pendapat masyarakat dengan kata-kata wartawan sendiri. Berbeda dengan pendapat langsung ditulis apa adanya sesuai pernyataan narasumber, pendapat tidak langsung sudah mengalami framing oleh wartawan. Isi pendapat tidak langsung biasanya sama dengan pendapat langsung karena ditulis dengan kata-kata yang berbeda oleh wartawan, kemungkinan untuk diperhalus dan dibiaskan cukup besar.

Banyaknya kutipan pendapat tidak langsung yang dimuat tidak lepas dari instruksi pimred yang meminta seluruh wartawan TK menulis laporan dengan bahasa yang baik, santun, dan menghindari kritik yang kasar. Eufemisme atau penghalusan kata justru disarankan oleh pimred untuk menghindari kemungkinan isi TK dianggap terlalu mengkritik pemerintah. Akan tetapi, kutipan tidak langsung memungkinkan wartawan TK secara leluasa memasukkan frame pribadinya ke dalam pendapat narasumber tanpa khawatir mendapatkan komplain.

Hal menarik lain yang ditemukan dari analisis isi TK adalah adanya fakta bahwa sebanyak $85 \%$ nada artikel yang dimuat di TK tahun 2006 - 2010 adalah bernada netral atau tidak positif dan tidak negatif, $12 \%$ positif atau propemerintah dan hanya 3\% yang nadanya negatif atau antipemerintah. Hasil tersebut menunjukkan, pemberian porsi yang besar terhadap ketermuatan pendapat masyarakat tidak serta-merta menyebabkan masyarakat dapat menyampaikan aspirasi secara bebas dan terbuka melalui TK. Dalam kenyataannya, pendapat masyarakat yang dimuat adalah pendapat yang sudah melalui penapisan ketat dari pengelola TK dan pimpinan birokrasi sehingga isinya dipastikan netral dan tidak menunjukkan suara nyata masyarakat di lapangan. Di samping itu, terdapat kemungkinan anggota masyarakat yang dijadikan narasumber TK adalah mereka yang sudah dipilih terlebih dahulu, yang suaranya netral, atau bahkan telah diatur sebelumnya agar berbicara sesuai arah yang dikehendaki oleh wartawan TK.

Jurnalisme pesanan atau embeded journalism tampak nyata terjadi di TK. Pada praktik, banyak fakta dan data yang sudah dikonstruksi terlebih dahulu oleh reporter, baru kemudian dimintakan quotes dari anggota masyarakat. Dengan kata lain, pendapat masyarakat hanya sekadar 
dijadikan pelengkap agar hasil liputan wartawan TK memenuhi kaidah cover bothside. Sepintas, anggota masyarakat dapat dengan mudah mengekspresikan pendapat langsung atau tidak langsung melalui TK. Apabila dicermati lebih dalam, mayoritas ekspresi masyarakat tersebut bersifat artifisial atau buatan, ekspresi yang sudah ditata agar sesuai dengan perspektif kepentingan penguasa atau kelompok dominan (Gurevitch dkk, 1982).

Seluruh hasil analisis dilema terkait implementasi elemen-elemen demokrasi pers di TK di dalamnya menunjukkan adanya kontestasi di ruang berita (Ishadi, 2002). Kontestasi terjadi antara kelompok antidemokrasi yang menginginkan keberpihakan kepada pemerintah dan kelompok prodemokrasi yang menginginkan keberpihakan kepada masyarakat. Kontestasi yang terjadi secara terus-menerus dalam rentang tahun 2006 - 2010 menimbulkan situasi dan kondisi dilematis yang sulit disikapi oleh pengelola TK. Pada akhirnya, dilema yang terjadi tidak menghasilkan resultan yang jelas sehingga sulit ditentukan apakah TK telah mengarah ke pers birokratik demokratis ataukah sebaliknya mengarah ke pers birokratik nondemokratis.

\begin{tabular}{lccc}
\multicolumn{3}{c}{ Keberhasilan sekaligus } & kegagalan \\
TK & dalam melakukan & diferensiasi \\
saat mencoba menangkap & perubahan
\end{tabular} lingkungan eksternalnya membuat TK tidak mampu tampil sepenuhnya sebagai entitas pers birokratik demokratis, tidak pula sepenuhnya menjadi pers birokratik nondemokratis (Maturana, 1981:90). TK berada di pendulum yang mengayun di antara kedua sistem tersebut, kadang sangat demokratis, kadang biasa saja, tetapi kadang juga sangat tidak demokratis. Karakteristik nondemokratis masih tampak menonjol di TK. Kondisi tersebut mirip dengan sistem pers swasta di era orde baru yang sulit dikategorikan ke dalam sistem pers normatif yang ada, kendati ciri khas pers otoritarian lebih dominan (Gunarjo, 2006:24).
Situasi dan kondisi dilematis muncul karena dalam waktu yang bersamaan pengelola TK harus membagi keberpihakan kepada dua domain yang secara politis berbeda kutub, yakni kepada pemerintah dan masyarakat. Keduanya memang dapat dipilih, dapat juga memilih berpihak ke salah satu, tetapi apapun pilihan yang diambil pengelola TK, hasilnya tetap tidak ada yang memuaskan. Situasi yang tidak pasti tersebut menyebabkan pengelola TK mengalami double bind dilemma (Bateson, 1956:251). Pengelola TK

mengalami kebingungan karena menerima dua pesan yang saling menegasikan satu sama lain, tetapi keduanya harus dilaksanakan secara bersamaan. Hal itu menyebabkan situasi di mana keberhasilan merespon satu pesan akan menghasilkan kegagalan merespon pesan lainnya, demikian pula sebaliknya. Dalam praktik, jika hanya berpihak kepada masyarakat, pengelola TK akan dipersalahkan karena sebagai humas pemerintah TK memiliki tugas untuk meningkatkan citra positif pemerintah yang berarti harus berpihak kepada pemerintah. Sebaliknya, jika hanya berpihak kepada pemerintah, pengelola juga akan dipersalahkan karena TK memiliki tugas sebagai wahana demokratisasi yang berarti harus berpihak kepada masyarakat.

Dilema yang sulit dihindari dalam praktik kerja jurnalistik di TK tersebut pada akhirnya memunculkan sikap ambigu, yaitu sikap mendua atau menjadi dua (Wojowasito dan Purwadarminta, 1996). Sikap ambigu terpaksa dilakukan pengelola TK agar dapat menjalankan dua peran sekaligus sebagaimana dikemukakan Cohen (1963) yaitu peran netral sebagai pemberi berita, penafsir dan alat pemerintah di satu sisi, peran pemeranserta sebagai wakil publik, pengkritik pemerintah, lawan pendukung kebijakan, dan penentang pembuat kebijakan di sisi lain. Pada posisi yang ambigu inilah, pengelola TK berupaya menjalankan kedua peran tersebut secara aman (McQuail, 1987:275). 

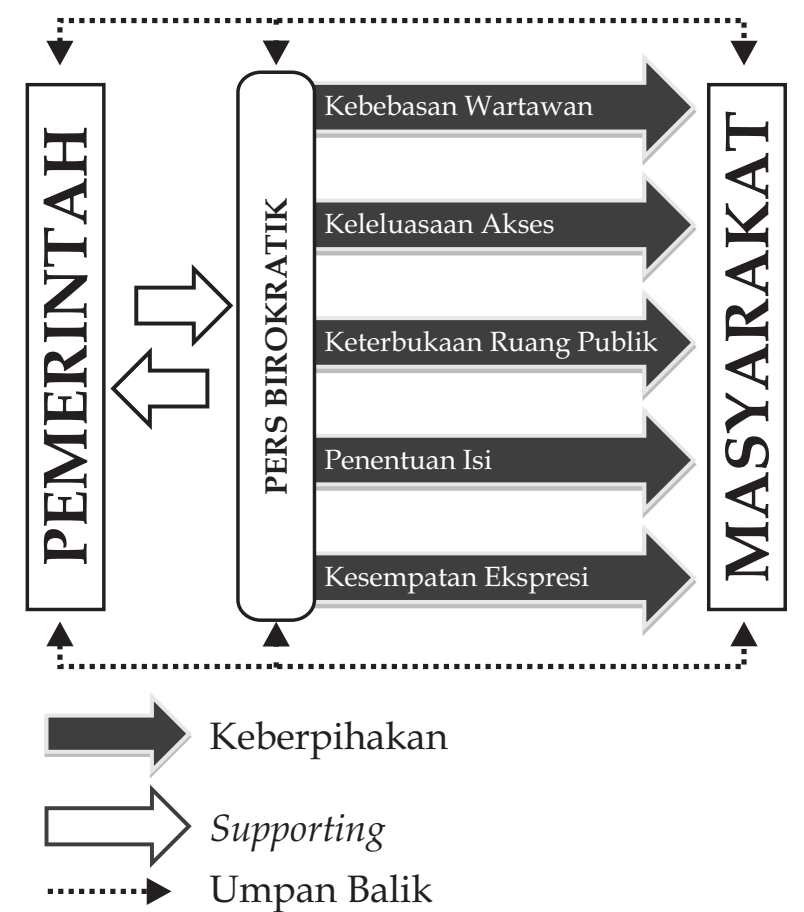

Gambar 2. Model Pers Birokratik Demokratis

Cara paling mudah yang dapat ditempuh adalah dengan mereduksi intensitas masingmasing peran sehingga berada dalam zona yang dapat diterima oleh pemerintah maupun masyarakat. Untuk dapat berfungsi sebagai wahana demokratisasi yang efektif, atau sebaliknya sebagai humas pemerintah yang baik, TK seharusnya menghilangkan dilema yang ada di dalamnya. Keberpihakan TK perlu diperjelas agar mengarah ke salah satu domain kepada pemerintah saja atau sebaliknya kepada masyarakat saja. Jika pilih-annya adalah menjadi wahana demokratisasi yang efektif, maka TK seharusnya menerapkan Model Pers Birokratik Demokratis seperti pada gambar 2. Sebaliknya, jika menginginkan TK menjadi media untuk mengoptimalkan tugas dan fungsi Kemkominfo sebagai pelaksana kehumasan pemerintah, maka TK seyogyanya menerapkan Model Pers Birokratik Nondemokratis seperti pada gambar 3 karena tujuannya adalah untuk menghilangkan dilema, maka pilihan model pers yang akan digunakan bukan opsional, tetapi merupakan pilihan tunggal.

Hal ini, dapat dipilih satu dari dua model yang ada. Kedua model merupakan pengembangan dari Model Eksisting Dilema di TK, dengan mengubah keberpihakan sesuai dengan tugas dan fungsi yang diinginkan. Dalam Model Pers Birokratik Demokratis keberpihakan pengelola TK saat menerapkan elemen demokrasi pers seluruhnya diarahkan ke masyarakat.

Pers birokratik demokratis dapat diwujudkan apabila implementasi elemenelemen demokrasi pers seluruhnya diarahkan untuk berpihak kepada masyarakat. Di sisi lain, masyarakat diberi keleluasaan untuk menyampaikan umpan balik baik melalui pers birokratik maupun langsung kepada pemerintah. Pemerintah dalam hal ini hanya berfungsi sebagai lembaga pendukung (supporting) pers birokratik dalam melayani masyarakat dan pers birokratik mendukung pelayanan pemerintah kepada masyarakat.

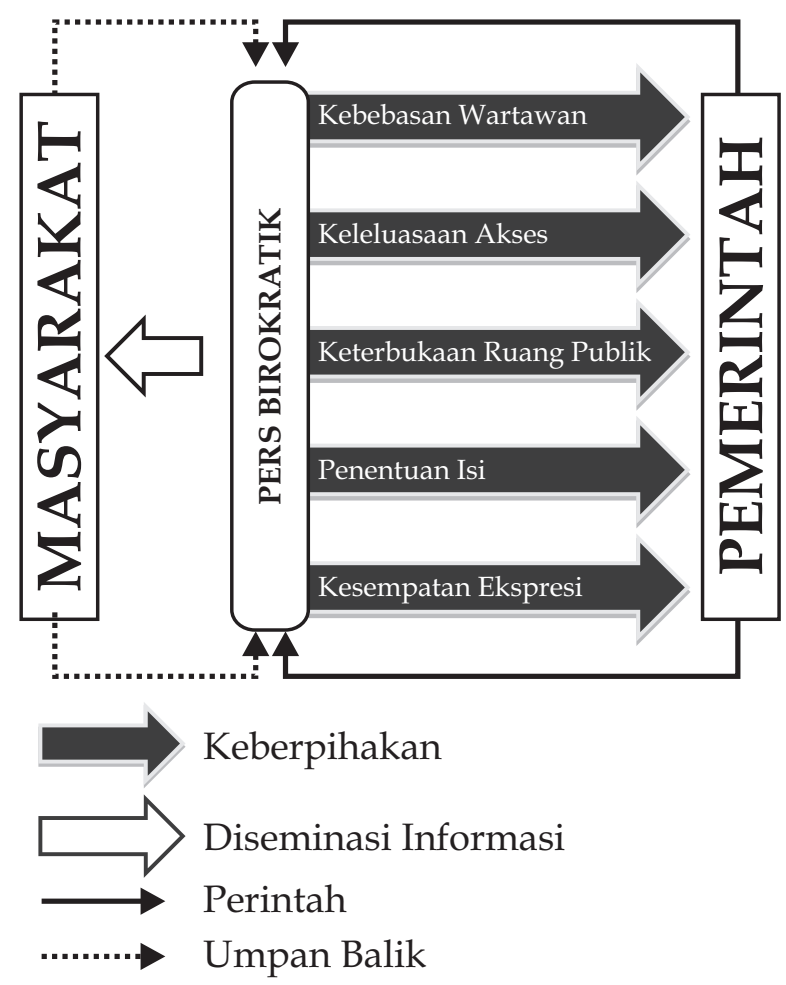

Gambar 3. Model Pers Pemerintah Nondemokratis

Sedangkan dalam Model Pers Pemerintah Nondemokratis, keberpi-hakan pengelola saat menerapkan elemen de-mokrasi pers seluruhnya diarahkan ke pemerintah. Pers birokratik nondemo-kratis dapat diwujudkan 
apabila implementasi elemen-elemen demokrasi pers diarahkan sepenuh-nya untuk berpihak kepada pemerintah. Pemerintah bukan sekadar se-bagai lembaga supporting, tetapi juga meng-arahkan aktivitas pers birokratik sebagai alat untuk mendiseminasikan program dan kebijakan pemerintah secara searah kepada masyarakat. Selain itu pers birokratik secara aktif dapat digunakan sebagai media pencitraan mengenai keberhasilan kinerja pemerintah dan aparat pemerintah, serta sarana untuk membina hubungan baik antara pemerintah dan masyarakat. Feedback atau umpan balik dari masyarakat dapat disampaikan melalui rubrik opini yang ada di dalam pers birokratik.

\section{SIMPULAN}

Dilema diTKterjadikarenaimplementasi demokratisasi pers di TK berlangsung tidak konsisten, kadang menguat kadang melemah. Ketidakkonsistenan terjadi adanya tarik-menarik kepentingan antara kelompok prodemokrasi dan antidemokrasi pers di dalam TK. Kelompok prodemokrasi berupaya menerapkan elemen-elemen demokrasi pers di TK, sementara kelompok antidemokrasi berusaha mempertahankan kemapanan status quo pers birokratik Orde Baru yang masih eksis di TK. Hegemoni kelompok antidemokratisasi menyebabkan implementasi demokrasi pers di TK berulang-kali mengalami reversal ke kondisi yang tidak demokratis. Tarik-menarik kepentingan antara kelompok pro dan antidemokrasi terjadi secara terus-menerus di TK, menimbulkan situasi dan kondisi yang tidak pasti. Ketidakpastian menimbulkan dilema, yang menyebabkan pengelola TK mengalami kebimbangan untuk memilih berpihak kepada masyarakat atau pemerintah. Pengelola TK akhirnya memilih berpihak kepada keduanya, karena intensitas pengaruh birokrasi pemerintah terhadap TK lebih besar, titik berat keberpihakan pada akhirnya lebih condong kepada pemerintah.

Faktor-faktor yang menyebabkan dilema di TK adalah rendahnya komitmen pimpinan untuk menerapkan demokrasi pers, tidak jelasnya struktur organisasi TK, ambiguitas fungsiTK, danketidakjelasansikappengelolaTK. Rendahnya komitmen pimpinan menyebabkan kebimbangan pengelola saat menerapkan demokrasi pers karena tidak ada dukungan kebijakan dan kontrol implementasinya di lapangan. Struktur organisasi TK yang berada di antara unit kerja nonstruktural dan struktural menyebabkan kesulitan pengelola dalam menegakkan independensi sebagai awak pers atau melaksanakan tugas dan fungsi sebagai aparat birokrasi. Ambiguitas fungsi TK sebagai wahana demokratisasi dan media humas pemerintah yang saling bertentangan satu sama lain menimbulkan dilema antara berpihak kepada masyarakat atau pemerintah. Sikap pengelola yang terpecah antara pro dan antidemokrasi pers, menyebabkan kebingungan karena adanya kemenduaan sikap antara mendukung dan menentang demokratisasi.

Dilema di dalam organisasi TK berpengaruh terhadap produk jurnalistik yang dihasilkan. Akibat adanya dilema, artikel TK lebih banyak memuat kutipan pendapat masyarakat umum daripada kutipan pendapat pejabat pemerintah. Akan tetapi, nada artikel yang dimuat di TK mayoritas adalah netral atau tidak pro ataupun menentang pemerintah. Pemuatan pendapat masyarakat umum dalam jumlah lebih banyak menggambarkan upaya pengelola TK untuk berpihak kepada masyarakat, tetapi isi yang netral menggambarkan bahwa pengelola TK berupaya berpihak kepada pemerintah. Pengelola TK melakukan rekayasa agar aspirasi masyarakat yang dimuat di TK tidak mengkritisi pemerintah.

Dilema di dalam pers birokratik dapat dihindari dengan menerapkan Model Pers Birokratik Demokratis atau Model Pers Birokratik Nondemokratis. Dengan menerapkan salah satu model, pers birokratik dapat memposisikan diri secara tegas sebagai wahana demokratisasi yang berpihak kepada masyarakat atau sebagai media humas pemerintah yang berpihak kepada pemerintah. 


\section{DAFTAR PUSTAKA}

Badan Informasi Publik, 2008, Roadmap Badan Informasi Publik 2005-2009, Jakarta.

Bateson, G., Jackson, D. D., Haley, J. \& Weakland, J, 1956, “Towards a Theory of Schizophrenia," Behavioral Science, Vol 1, 251-264.

Cohen, B, 1963, The Press and Foreign Policy. Princeton: Princeton University Press.

Creswell, W, John, 2010, Research Design, Pendekatan Kualitatif, Kuantitatif, dan Mixed. Yogyakarta: Pustaka Pelajar.

Cuilenberg, J.J., van, McQuail, D, 1998, "Media Policy Paradigm Shift, in Search of a New Communication Policy Paradigm," in Picard, G. (ed.) Evolving Media Market, Effect of Economic and Policy Changes, Turku, Finland: Economic Research Foundation for Mass Communication.

Dahl, R. A, 1999, On Democracy, New Haven: Yale University Press.

Dhakidae, D, 2007, “Memilih Media Penyebaran Informasi Publik", makalah dalam Temu Pakar Pengelolaan Informasi Publik, Jakarta.

Fishman, M, 1982, "News and Non-events: Making the Visible Invisible" in Ettema, J. S., Whitney, D. C., Individuals in Mass Media Organizations, pp. 219-40, Baverly Hills and London: Sage Publications.

Fortner, R. S, 1993, International Communication: History, Conflict, and Control of the Global Metropolis, Belmont, California: Wadsworth Pub. Co.

Gerbner, G, 1969, “Institutional Pressures on Mass Communication", in Halmos, P. The Sociology of Mass Media Communicators, Keele: University of Keele.
Gieber, W, 1956, “Across the Desk: A Study of 16 Telegraph Editors" Journalism Quarterly 33: 423-33.

Gunarjo, N, 2006, Subjektivitas Pers birokratik, Tesis Master Manajemen Pemerintahan dan Politik Lokal Universitas Airlangga.

Gurevitch, M., Bennet, T., Curran, J., Wollacott, J. (eds.), 1982, Culture, Society and The Media, London: Methuen.

Habermas, J, 1989, Ruang Publik, Sebuah Kajian tentang Kategori Masyarakat Borjuis, Yogyakarta: Kreasi Wacana.

Hallin, D. C. \& Mancini, P, 2004, Comparing Media System, Cambridge University Press.

Ishadi, S.K, 2002, Kontestasi di Ruang Berita Televisi: Analisis Kritis Praktik Diskursus Menjelang Jatuhnya Soeharto, Disertasi Doktor Universitas Indonesia.

Kusumastuti, F, 2004, Dasar-dasar Humas, Jakarta: Ghalia Indonesia.

Maturana, H. R, 1981, "Autopoiesis", in Zeleny, M., (ed.), Autopoiesis: A Theory of Living Organization, New York: North Holland.

McCormack, T, 1961, "Social Theory and the Mass Media", Canadian Journal of Economics and Political Science 4: 47989.

McQuail,D., 1977, Analysis of Newspaper Content, Royal Comission on The Press Research Series 4, HMSO.

McQuail, D, 1987, Teori Komunikasi Massa, Suatu Pengantar, Edisi Kedua, Jakarta: Penerbit Erlangga.

McQuail, D, 2000, Mass Communication Theories, Fourth Edition, London: Sage Publications.

Olusegun, O. W, 2006, Principles and Practice of Public Relations, Lagos, Abuja: National Open University of Nigeria. 
Pool, I. de S, 1983, Technologies of Freedom, Cambridge, Mass: Belknap Press of Harvard University Press.

Pusat Penelitian Sumber Daya Manusia dan Lingkungan Universitas Padjadjaran Bandung, 2000, Peranan Penerangan dalam Masyarakat, Laporan Hasil Penelitian.

Robbins, S.P., 2007, Perilaku Organisasi, Jakarta: PT. Indeks.

Sphichal, S., Wasco, J. (eds.), 1993, Communication and Democracy, Norwood, New Jersey: Ablex Publishing Corporation.

Steemers, J, 2000, “Broadcasting is Dead, Long Live Digital Choice" in Mackay, H., and O'Sulivan, T., (eds.), The Media Reader: Continuity and Transformation, London: Sage.

Subiakto, H, 2001, “Menggagas Sistem Media yang demokratis untuk
Indonesia Baru", Jurnal Ikatan Sarjana Komunikasi Indonesia, 6 (11). 9 - 29, Bandung: ISKI - PT Remaja Rosdakarya.

Severin, W. \& Tankard Jr, JW, 2005, Communication Theoires, Five Edition, Jakarta: Kencana.

Sullivan, M, 2009, A Responsible Press Office, An Insider's Guide, Terarsip dalam http//:www.usinfo.state.gov.

Webster, D, 1992, Building Free and Independent Media, New York: Routledge.

White, D. M, 1950, “The Gatekeeper: a Case Study in the Selection of News", Journalism Quarterly 27: 383-90.

Wojowasito, P.W.J.S., 1996, Kamus Besar Bahasa Indonesia, Jakarta: Gramedia.

Yin, R. K, 2008, Studi Kasus: Teknik dan Metode, Jakarta: Rajawali Press. 